\title{
On Cultivating Liaoning Scientific Foreign Language Talents under the Influence of New Media
}

\author{
Huanhuan $\operatorname{Ren}^{1, a}$, Chi Ma ${ }^{2, b}$ \\ ${ }^{1}$ Teaching and Research Institute of Foreign Languages, Bohai University, Jinzhou, 121013, China \\ ${ }^{2}$ Jinzhou Institute of Forestry Research, Jinzhou Forestry Bureau, Jinzhou, 121013, China \\ a email: renhuanhuan2014@163.com, bemail: machi2014@tom.com
}

Keywords: Cultivating; Liaoning Scientific Foreign Language; New Media

\begin{abstract}
New media technologies have grown and flourished in china and it's vital that learning community as a whole understands what new media actually represent. The insights into Liaoning scientific foreign language talents have been highlighted from the potential problems occurring in the traditional learning setting to the practical promise possibly given with state of the art technologies of new media. The major argument of the thesis is that if the cultivation of ESP proficiency, the cultivation of communicative skills, and the cultivation of cultural awareness are stressed and incorporated in foreign language pedagogy by foreign language teachers in Liaoning province, the foreign language competence of Liaoning scientific foreign language talents is more likely to be enhanced and fostered with the aid of new media technologies.
\end{abstract}

\section{Introduction}

With current trends and advances in media technology, China has made great strides in pushing development in sectors that are key to the emergence of new media, and benefits of a high speed of development in industries may accrue from making advantage of new media technologies. To understand new media and technologies, and to critically reflect upon them in the educational scene, this paper details one study conducted in foreign language learning classroom in Liaoning province of china for scientific foreign language talents. The issue of insights into Liaoning scientific foreign language talents under the influence of new media is highlighted in this research and the dimensions of cultivating Liaoning scientific foreign language talents are profoundly argued under the influence of new media, in hope that Liaoning scientific foreign language talents are more likely to demonstrate their foreign language competence in workplace.

\section{The Developments of New Media in Chinese Context}

The Interne as a global new medium. What is new media? The word of new media is in relation to old media forms (i.e. radio, television, telephone, magazine, newspaper). Then what's new about new media? New media refer to the forms of mass communication using digital technologies such as the Internet. As many have noted, the concept of new media is a general idea of being online via the Internet. The gist, in somewhat simpler terms, is that it's about moving from a passive one-way communication pattern to an active two-way one. The key point in new media is the access to Internet no matter it's on fixed computer or on a mobile device. It's found that the advent of the Internet is the real catalyst for many important advances, and it make it real to shift from old media to new media. It's common that too often we see people are leveraging "Internet of Things". The evidence is also overwhelming that new media is beginning to take hold as the content provided by new media is rather interactive and dynamic. In sum, new media make it possible for anyone, from adults to kids, to create, modify, and share content and share it with others, using relatively simple new media tools that are often free or inexpensive.

Technologies behind new media. The advent of new communication technology (NCT) has brought forth a set of opportunities and challenges for conventional media[1]. Recent advances in new communication technologies are not only changing how people interact with each other, but 
also redefining our notion of new media. New media supported by new communication technologies can create new environments that produce more open, fluid, and dynamic learning environments. According to Wikipedia, most technologies described as new media are digital, often having characteristics of being manipulated, networkable, dense, compressible, and interactive. Some examples may be the Internet, websites, computer multimedia, video games, virtual reality, augmented reality, CD-ROMS, and DVDs[2]. New media technologies got its start in the 1960s and became highly prevalent in the 1980s. The idea for the Internet, like the personal computer, came from the heads of the information technology department of the Defense Advanced Research Projects Agency (DARPA), and it's developed primarily for military and scientific applications throughout the 60's and 70's in the US[3]. The rise of the Internet has been one of the most transformative developments in human history. It's agued that new communication technologies are slowly replacing traditionally media, primarily through the implementation of personal computers, mobile phones and video game systems.

New media in China. China's new media market has presented vigorous development momentum and the new media industry in china has been at a high speed of development recent years. According to some document in 2004, estimates put the worldwide online population at a staggering 580 million, and more than half our population were actively using the largest information repository in human history[4]. The Chinese media context has seen intense changes over the past few decades. It's projected that China's internet population will hit 718 million by 2013, comfortably the largest base of net users in the world[5]. China has made great strides in pushing development in sectors that are key to the emergence of new media, such as mobile telecommunications and information technology, and the fast expansion of network coverage has fueled a surge in the variety of Internet applications, which range from instant messaging and video-sharing to shopping and banking, as well as social networking[6]. Numerous explanations have been proposed and debated concerning why china developed so fast. According to New Media for a New China, "China is vast and so are its communications-more computers, more-emails, more cell phone messages, more films and music videos and larger audiences for more television programs. And whether by cable or satellite there are messages that are threatening the existing social order. China's media are right in the middle of all changes and struggles[7]”.

\section{The Insights into Liaoning Scientific Foreign Language Talents under the Influence of New Media}

The problems of Liaoning scientific talents in foreign language learning. One of the common criticisms leveled at foreign language learning is the less satisfactory learning outcomes. In spite of a large amount of time put into the foreign language process, it could be argued that foreign language learners, including Liaoning scientific talents are still faced with enormous difficulties in learning. The explanation for being less efficient in foreign language learning is twofold. On one hand, traditional teaching is not conducive to the development of language proficiency. Foreign language teachers in Northeast China, including Liaoning province, are particularly focusing on the reading and writing abilities of language learners more than listening and speaking ones. Moreover, in the context of education in China, students are often described to be passive in class and familiar with rote learning. Teachers are used to dictating the class and do not give students enough opportunities to express themselves. In this regard, it's common that the communicative skills of foreign language learners is far from being satisfactory. On the other, the foreign language learning for scientific talents in Liaoning province does not aim at being competent in finding job opportunities after graduation, but rather it's stressed by them to pass all kind of foreign language tests through doing a large amount of similar exercises. In other words, in China generally, students haven't got a specific purpose of studying English, and don't' have the motivation to find out what is necessary to actually achieve it. Teachers nowadays are less aware of the importance of a well motivated learning in foreign language learning. In a word, efforts should be made to help in this endeavor in foreign language learning so that the problems of Liaoning scientific talents in foreign language learning can be hopefully solved at its source. 
The promise of new media on Liaoning foreign language scientific talents. New media technologies provide more opportunities to transform the way of learning foreign language for scientific talents. Above all, a wealth of learning material can be accessed by Liaoning scientific foreign language talents as required through the use of new media. As many have noted, learners are able to navigate in the wild digital world complete with resources which are set to meet specific needs of the learners. It's suggested that scientific talents be more likely to be popular in labor force market if they are equipped with foreign language abilities concerning with the specific field they are specialized in. The courses offered by teachers could cover subjects varying from accounting or computer science to tourism and business management. The learning environment can be moving toward a more interactive and dynamic one as new media gives learners the opportunity to develop language and communication skills in a friendly, lively, creative and cosmopolitan way. It's true that online learning concentrates more on language in context than on teaching grammar and language structures, and the focal point of learning utilizing new media is that foreign language is not taught as a subject separated from the students' real world, but it is integrated into a subject matter area important to the learners. Lastly, new media can help learners take charge of their language learning through enabling learners study at any time and at any place. And the neglect of learner autonomy in foreign language learning lead learners to a passive situation where more decision are made by others. It's hoped that social media ensures foreign language learners have opportunities to explore the area, make friends, and develop foreign language skills outside the classroom.

\section{The Cultivation of Liaoning Scientific Foreign Language Talents based on New Media Technologies}

In order for Liaoning scientific foreign language talents to enhance their foreign language abilities based on new media technologies, Liaoning scientific talents are encouraged to posses foreign language abilities of at least three areas: the cultivation of ESP proficiency of Liaoning scientific talents, the cultivation of communicative skills of Liaoning scientific talents, and the cultivation of cultural awareness of Liaoning scientific talents, as shown in Fig. 1. The three directions could make the pedagogical mode more comprehensive and more conducive.

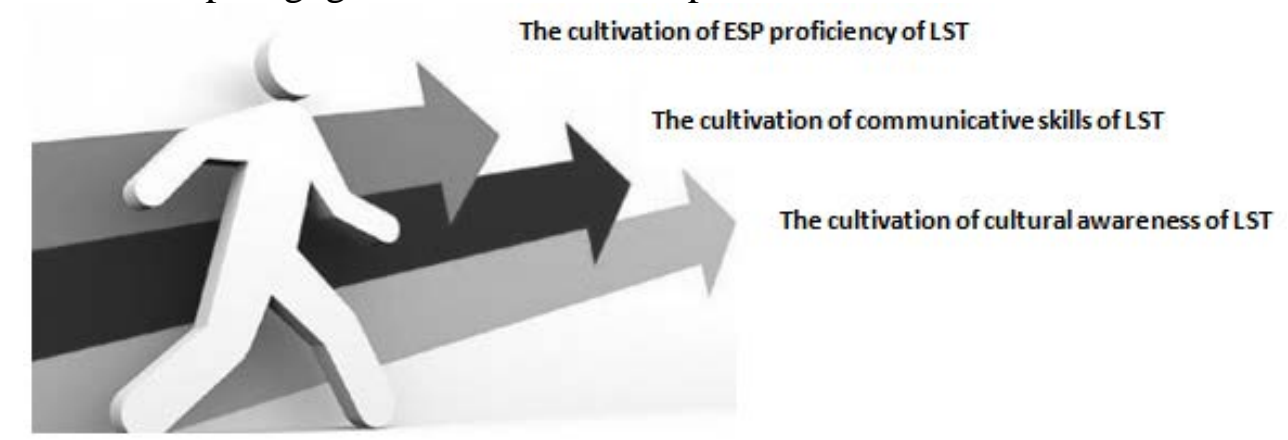

Fig.1. The cultivation of Liaoning scientific talents (LST) in foreign language

The cultivation of ESP proficiency of Liaoning scientific talents. Some of the more obvious benefits of foreign language learning may accrue from cultivating ESP (English for Special Purposes) proficiency of scientific learners. ESP, in china, has had a relatively long time to mature but the movement has shown a low growth over the past few years. Too often we see foreign language instructors in Liaoning province of china are relying much on a general English approach for all students, and it's proved to be a learning process in defiance of specific needs of learners with scientific background. Just as Hutchinson et al. put in a simple way, "in theory nothing, in practice a great deal", when one ask what the difference between the ESP and EGP (English for general purpose) is[8]. For ESP learning, foreign language learning should be involved in discourse for specific communities to meet needs of the learner. It aims at helping learners to communicate a set of professional skills and performing particular job-related functions. In this respect, there should be a rapid growth in foreign language courses concerning specific disciplines (e.g. English for physics, English for mechanical engineering, etc.) as opposed to general English courses (e.g. 
college English). Moreover, an ESP program is also anticipated to built on an assessment of purposes and needs and the functions for which English is required. In other words, teachers are encouraged to conduct interviews with specialists in the field, analyze the language that is required in the profession, and conduct students' needs analysis. In brief, ESP has grown to become one of the most prominent areas of EFL teaching, and foreign language instructors ought to take action in this endeavor with a number of ESP courses offered to scientific students in Liaoning province.

The cultivation of communicative skills of Liaoning scientific talents. There are many reason for communicative skills in foreign language learning for scientific talents in Liaoning province, so instructors are supposed to think very carefully about how to cultivate communicative skills of each foreign language learner. Despite the fact that foreign language has functioned in China for two hundred years, language teaching and learning have made a poor show. Learners who are frustrated with memorizing endless lists of vocabulary and mastering all the grammar need to hold any conversation, still find themselves at a loss when wanting to express themselves. The evidences is overwhelming that learners talk like old books when they speak, since they don't communicate in most cases. Instructors should keep in mind that they are anticipated to offer class for those who see effective communication as a vital factor in workplace and wish to improve their everyday English communication skills or enhance their command of English for professional purposes. The idea of enhancing communicative skills is to make the classroom contexts and situations come closer to the real-life ones, no matter how artificial or simulated we may think that the teaching and learning environment is. Otherwise, many tasks in task-based courses are purposeless because nothing is done with students' output and it does not lead anywhere. In brief, the ever-growing need for good communicative skills has created a huge demand for foreign language teaching in china, and teachers should collaborate with scientific students to enhance foreign language workshops across Liaoning which is essential to their individual development in communities.

The cultivation of cultural awareness of Liaoning scientific talents. There is some truth about the idea of moving to the trend towards the incorporation of cultural awareness in foreign language learning. Language and culture are inseparably linked to each other. Unless understanding the culture of the target language can learners use the language in an accurate and appropriate way. In other words, an integral part of learning a foreign language is acquiring more familiarity with the culture associated with it. Increasingly, language teachers in china are recognizing the need to incorporate sociocultural factors into their classrooms. However, among Chinese English-learners, it is common that they create chinglish whilst in Chinese way of thinking. To avoid unexpected misunderstanding caused by ignorance of cultural difference, it's important to carry on cultural teaching. It could be argued that having respect for someone's culture breaks down barriers of communication and makes your students feel at ease. It's suggested that cultural awareness begin with developing sensitivity and understanding of students' beliefs, attitudes and values, and they need familiarize themselves with cultural characteristics, history, values, belief systems, and behaviors in the targeted language country through the magic of new media technologies. Learners are required to acquire knowledge about other cultures by reading books or watching movies, and attending cultural events and festivals. In a word, teachers should help students connect to the target culture, raise their awareness of cultural differences, and improve their intercultural communicative competence through exploring various cultural elements in new media context.

\section{Conclusion}

New media technologies have grown and flourished in china and it's vital that learning community as a whole understands what new media actually represent. The insights into Liaoning scientific foreign language talents have been highlighted from the potential problems occurring in the traditional learning setting to the practical promise possibly given with state of the art technologies of new media. The major argument of the thesis is that if the cultivation of ESP proficiency, the cultivation of communicative skills, and the cultivation of cultural awareness are stressed and incorporated in foreign language pedagogy by foreign language teachers in Liaoning province, the foreign language competence of Liaoning scientific foreign language talents is more 
likely to be enhanced and fostered with the aid of new media technologies. Only in this endeavor can scientific foreign language learners join with confidence and carry on the practices in foreign language learning setting.

\section{Acknowledgement}

This work is part of the project of On Cultivating and Developing Liaoning Scientific Foreign Language Talents with View to Bourdieu' Theory. This research was supported by the fund of Liaoning Planning of Philosophy and Social Science (Project No. L16CYY001).

\section{References}

[1] Garrison, B., Successful Strategies for Computer-Assisted Reporting. Mahwah, NJ, USA: Lawrence Erlbaum Associates, 1996

[2] Flew, https://en.wikipedia.org/wiki/New_media\#cite_ref-2, 2008

[3] Retrieved from http://www.longviewinstitute.org/projects/marketfundamentalism/internet/

[4] Mike H.,The rise and rise of the Internet, http://newatlas.com/go/1595/, 2004.

[5] [6] Yin Y. G., Report on China's Rising New Media. Paths International Ltd, 2013.

[7] James F. S. and William A. H. New Media for a New China, Wiley-Blackwell, 2010.

[8] Hutchinson, T. And Waters, A. English for Specific Purposes: A learner-centered approach. Cambridge University Press, 1987. 